DOI 10.31392/NPU-nc.series 2.2019.21(28).01

УДК: 004.934:004.43(=161.2)

\author{
М. І. Жалдак \\ академік НАПН України, заслужений діяч науки і техніки України, \\ доктор педагогічних наук, професор \\ Національний педагогічний університет імені М. П. Драгоманова
}

\title{
ДЕЯКІ ОСОБЛИВОСТІ УКРАЇНОМОВНОЇ ІНФОРМАТИЧНОЇ ТЕРМІНОЛОГІЇ
}

Анотація. В статті аналізуються деякі проблеми україномовного подання змісту науковопедагогічних публікацій, пов'язаних з впровадженням в навчальний процес в закладах середньої і вищої освіти сучасних інформаційно-комунікаційних технологій, їх наукової і педагогічної виваженості і обгрунтованості. Зокрема аналізується коректність термінів «електронне навчання», «електронна педагогіка», «інтерактивні засоби навчання», «інтерактивні інформаційні системи», «можливості хмарних технологій», «цифрове суспільство» тощо, тверджень типу «компетентність це спроможність» (або «компетентність - це здатність»), взаємозв'язки понять «компетентність» і «компетенція» тощо.

Звертається увага на необхідність подання змісту науково-педагогічних публікацій на якомога високому літературному і загальнокультурному рівні для забезпечення їх позитивного впливу на навчання і виховання учнів і студентів, формування їхньої професійної і загальної культури.

Ключові слова: україномовна інформатична термінологія, науково і педагогічно виважена система навчання і виховання, культура науково-педагогічних публікацій, діяльність та ії структура, науковий підхід до тлумачення використовуваних термінів.

В останні роки в зв'язку із значним поширенням використання сучасних інформаційнокомунікаційних технологій в найрізноманітніших галузях людської діяльності, зокрема і в навчальнопізнавальній діяльності, в українській науково-педагогічній літературі стали використовуватися різноманітні іншомовні терміни: інформація, компетентності, компетенції, симуляція, симулятори, пірінг, парадигма, концепція, інтерактивні засоби навчання, інтерактивні підручники, інтерактивні дошки, інтерактивні програми, інтерактивні інформаційні системи, онлайн, креативність, аккаунт, квест, кейс, флешмоб, портфоліо, аспекти, блог, фейсбук, управління якістю освіти, електронне навчання, електронна педагогіка, цифрове суспільство та інші іншомовні «слівця», що використовуються окремими авторами мабуть для надання «фундаментальності» своїм науковим розробкам, їх теоретичної і практичної значущості, якомога вищого наукового рівня результатів наукових пошуків і здобутків.

Разом з тим таке «засмічування» україномовної науково-педагогічної літератури часто не тільки не підвищує іï науковий рівень, теоретичну і практичну значущість, а навпаки спотворює як україномовне подання здобутих результатів, так і виховний вплив подібних творів на їх читачів, зокрема студентів навчальних закладів вищої освіти та учнів навчальних закладів середньої освіти, наносить шкоду як професійному, так і загальнокультурному розвитку молодих людей, їх ставленню до рідної мови і культури, народних традицій, вишуканості подання наукових і загальнокультурних здобутків добірною українською мовою.

Не претендуючи на «істину в останній інстанції» і непогрішимість пропонованих положень, разом 3 тим розглянемо окремі інформатичні поняття 3 позицій за можливості «логіки речей $\mathrm{i}$ здорового глузду» та педагогічно виваженого використання всіх складових систем навчання i виховання молодих людей, зокрема і формування в процесі навчання різноманітних понять, знань, умінь і навичок, та використання відповідних термінів.

Одним 3 найчастіше використовуваних термінів як в науково-педагогічній, так і в навчальній літературі, а також і в різних друкованих засобах та засобах оповіщення людей, $\epsilon$ термін «інформація» (в перекладі з латинської - information - повідомлення, відомості (див. [16]). В літературі названого призначення можна зустріти вислови «передавання інформації», «обробка інформації», «пошук інформації», «зберігання інформації», «захист інформації» і т.п. Разом з тим всі наведені вислови виявляються некоректними і позбавленими змісту. Як свідчать дослідження вчених, немає відповіді на питання «що таке інформація». «Це лише одна із сторін відображення в свідомості людини реалій оточуючого світу» [2]. «Мабуть неможливо знайти універсальний підхід до означення i оцінювання інформацї̈» [1]. Не слід також ототожнювати поняття повідомлення $i$ відомості. Спілкуючись, люди обмінюються повідомленнями, які можуть передаватися за допомогою 
різноманітних засобів (див., наприклад, [14]). Разом з тим одне і те саме повідомлення в залежності від різноманітних обставин різними людьми може бути витлумачене не однаково і для різних людей одне і те саме повідомлення може нести різні відомості (див. [14]). Навіть одна і та сама людина 3 плином часу в раніше отриманому повідомленні може знайти відомості, відмінні від побачених нею раніше залежно від розширення і поглиблення її обізнаності в різних галузях знань і в причиннонаслідкових зв'язках різноманітних проявів оточуючого світу.

Прикладами повідомлень можуть бути різні алгоритми і програми як описи того, які саме операції і в якій послідовності необхідно виконати, щоб отримати відповідний результат. Нотні записи є повідомленнями про те, як потрібно виконувати відповідний музичний твір.

Відео- і аудіозаписи є повідомленнями про відповідні події.

Навчальні посібники є збірниками повідомлень про те, як потрібно тлумачити відповідні поняття та які між ними існують взаємоз'вязки, в чому полягає сутність різних понять і тверджень, закономірностей, що мають місце у просторі досліджуваних об'єктів, висновків і правил, що випливають із сутності досліджуваних процесів.

Довідники, енциклопедії, словники також є збірниками повідомлень відповідного призначення.

Спостерігаючи за всеможливими проявами оточуючого світу, людина отримує відповідні

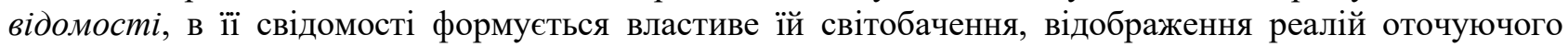
світу - знання про навколишній світ. Повідомити когось про побачене, почуте, відчуте можна лише через відповідні повідомлення. Однак, як відомо, повідомити комусь чи передати свої знання, реакцію на прояви світу, емоції, своє світобачення, жодна людина не може, оскільки кожна людина здобуває знання про оточуючий світ в процесі лише власної пізнавальної діяльності, в кожної людини формується властиве тільки їй світобачення через напруження власних пізнавальних зусиль, з'ясування всеможливих причинно-наслідкових зв'язків і сутності найрізноманітніших проявів оточуючого світу [14].

Слід зауважити, що в мережі Internet, на різноманітних електронних і паперових носіях, відео і аудіозаписах, картинах і т. д. немає ніякої інформації, а є лише всеможливими способами подані повідомлення стосовно найрізноманітніших проявів оточуючого світу. Через довжини таких повідомлень визначається ємність носіїв, які іноді називають запам'ятовуючими пристроями, потрібних для «запам'ятовування» і «зберігання» різноманітних повідомлень (див. [3]). Разом $з$ тим питання про «кількість інформації», «типи інформації» (звукова, цифрова, письмова, графічна, таблична тощо) $є$ некоректними.

Слід зауважити, що в «Теорії інформації» К. Шеннона (назву якої автор вважав невдалою) в разі обчислення ентропії (невизначеності) деякої системи, що може знаходитись в $n$ різних станах 3 імовірностями $p_{i}, i \in \overline{1, n}$, за формулою К. Шеннона $I=-\sum_{i=1}^{n} p_{i} \log _{2} p_{i}$, чи за формулою Р. Хартлі в разі рівноймовірних станів досліджуваної системи, мова йде лише про «кількість інформації» як про міру зменшення ентропії (міри невизначеності) системи в разі зменшення кількості ії невизначених станів. Ні про які відомості стосовно якихось явищ чи процесів не йдеться. Як відомо, сам К. Шеннон свою роботу, видану в 1948 році, назвав «Mathematical theory of communication» («Математична теорія зв'язку»), що стосувалася кодування і передавання різноманітних повідомлень через канали зв'язку.

В зв'язку з розглянутим вище питання про захист інформації, передавання інформації, зберігання інформації, пошук інформації, типи інформації тощо є некоректними і в разі їх використання підхід до вивчення і тлумачення наведених понять не може вважатися науковим підходом до аналізу відповідних проблем. За такого підходу до навчання основних понять інформатики в учнів формується неправильне світобачення, спотворюється їхня наукова і загальнокультурна підготовка, що поза сумнівами наносить шкоди розвиткові їхнього аналітичного і синтетичного мислення, творчого потенціалу, загальнокультурного розвитку.

Найбільш коректно розглядувані поняття на сьогоднішній день витлумачені в роботі [3].

Слід підкреслити, що соціально надважливими сьогодні $є$ не тільки проблеми захисту різноманітних інформаційних ресурсів, а перш за все проблеми інформаційної безпеки дітей і молоді (див. [17]).

Іншим часто використовуваним терміном в сучасній науково-педагогічній літературі $є$ термін «компетентність». В перекладі українською мовою слово «компетентність» означає «обізнаність» (див. [12]), тобто знання, уміння і навички, здобуті і сформовані в результаті навчально-пізнавальної діяльності і закріплені, розширені і поглиблені в процесі професійної діяльності і на основі життєвого досвіду. 
Разом $з$ тим в різних науково-педагогічних публікаціях 3'явилися такі словосполучення, як «ключові компетентності», «компетентнісно-орієнтовані підходи» до навчального процесу, «компетентнісні задачі», «ко-задачі» і т.п. «наукові знахідки». В деяких науково-педагогічних публікаціях, з перекручуванням і спотворюванням змісту слів, стверджується, що «компетентність це спроможність» (чи здатність) виконувати якісь дії (див. [8]), або навіть наводяться таблиці, в яких розкривається «структура компетентностей» - через перелік деяких «здатностей» (див. [9]).

Зрозуміло, що компетентність (обізнаність) людини (див. [12]) в деякій галузі діяльності $є$ підгрунтям, базою здатностей (спроможності) виконувати відповідну діяльність, оскільки відповідна обізнаність необхідна, щоб із знанням справи здійснювати певну діяльність.

Разом 3 тим в силу різних обставин компетентності може виявитись недосить для здатності (спроможності) людини виконувати певні дії, що може бути пов'язане із фізичним чи психічним станом людини чи деякими зовнішніми незалежними від людини чинниками.

Можна навести приклади, коли людина з роками втрачає здатність (спроможність) виконувати певні дії, хоч обізнаність у відповідній галузі діяльності не лише не збіднюється, а навіть збагачується, розширюється і поглиблюється.

Наприклад професійний спортсмен легкоатлет швидше за все в семидесятирічному віці вже не здатний демонструвати такі самі спритність і вправність у виконанні різних вправ, або результати в бігу на дистанцію 100 метрів, які він був здатний демонструвати в двадцятирічному віці. Разом 3 тим обізнаність у відповідній галузі знань у нього ніяк не зменшується і швидше за все розширюється і поглиблюється, тепер він здатен тренувати молодих спортсменів, навчати їх, як потрібно виконувати спортивні вправи, контролювати хід навчання, хоч сам такі вправи виконувати так само спритно і вправно він вже не здатний в зв'язку з відповідними природними змінами, що відбуваються в організмі кожної людини.

Подібних прикладів можна навести досить багато.

Таким чином ототожнювання понять компетентність і здатність (спроможність) є науково некоректним, воно не узгоджується $з$ логікою речей і сутністю відповідних понять.

Досить часто поряд 3 терміном «компетентності» без достатніх обгрунтувань і потреб використовується термін «компетенції» (українською мовою перекладається як «коло повноважень», див. [12]), шо також свідчить скоріш за все, що сутність поняття і термін «компетенції» використовуються без достатнього обгрунтування необхідності такого використання в україномовному поданні результатів відповідних науково-педагогічних досліджень (див. [8], [9] та ін.).

Ще один «модний» термін «інтерактивність» часто використовується без достатніх обгрунтувань в таких словосполученнях, як «інтерактивний підручник», «інтерактивна дошка», «інтерактивна програма», «інтерактивна інформаційна система», «інтерактивний засіб навчання» тощо (див. [4]), мабуть 3 метою тим самим підкреслити, що мається на увазі сучасний інформатизований навчальний процес 3 широким педагогічно виваженим використанням сучасних інформаційно-комунікаційних технологій, комп'ютерно-орієнтованих методичних систем навчання всіх без винятку навчальних предметів, 3 гармонійним поєднанням педагогічних надбань минулого 3 сучасними комп'ютеризованими технологіями підтримки навчально-пізнавальної діяльності учнів i наставницької навчальної діяльності вчителів.

Разом 3 тим досить звернути увагу на зміст слова «інтерактивність», що означає «взаємодія», «взаємопов'язана діяльність» (від англ. interact - взаємодіяти, interaction - взаємодія, див. [16]), а також на структуру діяльності - цілепокладання, планування діяльності, добір засобів діяльності, виконання дій, аналіз результатів діяльності (див. [11]), щоб збагнути, що засоби навчальнопізнавальної діяльності, до яких відносяться підручники, дошки, педагогічні та інші програмні засоби, комп'ютери тощо, ніяк не можуть бути інтерактивними і взаємодіяти з людьми. Разом 3 тим люди можуть використовувати такі засоби за відповідним призначенням, як засоби відповідних видів діяльності, для підтримки і забезпечення яких вони створені.

До некоректностей розглянутого типу відносяться і вислови на зразок «можливості комп’ютера», «можливості хмарних технологій» тощо (див, наприклад, [6]), хоч очевидно, що у штучно створених людьми засобів їхньої діяльності ніяких можливостей не буває, проте у людей є можливості їх використовувати за призначенням для здійснення відповідних видів діяльності.

Некоректним $є$ також словосполучення «Мета статті», що часто зустрічається в різних науковопедагогічних публікаціях. Разом з тим неважко переконатися, аналізуючи структуру діяльності людини, що у статті мети не буває і бути не може, мета пов'язана з діяльністю того, хто планує здійснювати ту чи іншу діяльність, щоб в результаті досягти певної мети (див., наприклад, [11]).

Із аналізу структури діяльності та сутності цього поняття (діяльність - спосіб буття людини в cвimi, див [11]) слідує, що навчання, як навчально-пізнавальна діяльність учнів та навчально- 
наставницька діяльність педагогів, не можуть бути електронними, хоч вислів «електронне навчання» іноді можна зустріти в деяких науково-педагогічних публікаціях. Разом 3 тим навчання 3 використанням різноманітних електронних засобів для підтримки здійснення навчально-пізнавальної діяльності цілком узгоджується з логікою речей і сутністю відповідних понять.

Іноді зустрічається і словосполучення «Електронна педагогіка». Важко збагнути, що мається на увазі, коли запроваджується в обіг таке словосполучення. Разом з тим, якщо врахувати, що педагогіка - наука про навчання і виховання підростаючих поколінь (див. [11]), а наука - одна із форм суспільної свідомості (див. [11]), соціально значуща сфера людської діяльності, ...наука є складовою духовної культури суспільства..., у філософському тлумаченні наука виступає як форма суспільної свідомості (див. [11]), то легко бачити, що педагогіка, як і будь-яка інша наука, не може бути електронною.

Слід взяти до уваги також, що до найважливіших теоретичних підвалин педагогіки відносяться філософія, зокрема теорія пізнання. Іншою важливою підвалиною педагогіки є психологія (зокрема педагогічна психологія). Оскільки не існує електронної філософії (і не може існувати, що слідує 3 наведеного), і не існує електронної психології (і не може існувати), то не може існувати і електронної педагогіки. Відповідне словосполучення не узгоджується з логікою речей і сутністю розглядуваних понять.

Слід зауважити, що в окремих науково-педагогічних публікаціях не завжди коректно використовують і інші терміни, окремі з яких тут проаналізуємо.

Часто, щоб виокремити чи підкреслити вагомість окремих фрагментів тексту, виокремлений фрагмент тексту називається «виділенням», хоч такий термін швидше медичний, аніж педагогічний.

Розв'язки задач часто називають рішеннями (можливо від російського «решение»), хоч в україномовному поданні задачі розв'язують (а не «решают») і в результаті отримують розв'язки (а не «рішення»). Разом з тим певні рішення люди приймають, попередньо їх обгрунтувавши, а розв'язки задач знаходять в процесі розв'язування задач. Те саме стосується словосполучення «Вирішити задачу» (можливо від російського «решить задачу»). Можливо тут варто нагадати, що задачі $\mathrm{i}$ проблеми люди розв'язують, завдання виконують, сутність явищ з'ясовують і т.д.

Часто можна зустріти вислови «вірна відповідь» чи «вірний розв'язок», хоч відповіді на запитання (чи розв'язки задач) бувають правильні або неправильні, а «вірні» бувають друзі. Твердження бувають вірогідні (краще ніж достовірні).

В разі використання в тексті науково-педагогічного твору слів іноземного походження (типу аккаунт, блог, симуляція, фейсбук, пірінг, онлайн і т.д.) в дужках потрібно наводити відповідні тлумачення термінів українською мовою, що аж ніяк не применшуватиме теоретичну і практичну значимість публікації і рівень ії науковості, а можливо навіть навпаки.

Слід також уникати некоректного подання українською мовою окремих термінів іншомовного походження. Наприклад тлумачення терміну «Симуляція» (див. [9]) (від англ. simulation) у Великому тлумачному словникові сучасної української мови подається як «придурювання» (див. [12]), а simulator 3 англійської мови перекладається як «притворщик» (див. [15]). Мабуть можна було б знайти більш коректні україномовні слова, аніж «симуляція», для опису відповідних об'єктів та можливостей їх дослідження і використання (див. [9]).

Навчаючи математики, інформатики, фізики та інших предметів, вчителі мають також формувати в учнів основи професійної і загальної культури, знання української літературної мови, культуру поводження в суспільстві, шанобливість, доброзичливість, ввічливість, чуйність, бережливе ставлення до оточуючого світу.

Поза сумнівом, в науково-педагогічних розробках і публікаціях окрім дотримання вимог подання текстів добірною літературною українською мовою, із зверненням в разі потреби до відповідних словників, необхідно дотримуватися також дидактичних принципів навчання, зокрема принципів науковості, доступності, зв'язків навчання з життям, систематичності та ін. Разом з тим всі компоненти системи навчання і виховання учнів мають бути педагогічно виваженими. Недотримання зазначених вимог може не лише не бути корисним для інтелектуального, загальнокультурного, духовного i фізичного розвитку учнів, але i наносити значної шкоди, особливо стосовно інтелектуального розвитку учнів, їхнього світобачення, аналітичного і синтетичного мислення, творчого потенціалу, дослідницьких задатків і здібностей. Головним $\epsilon$ аж ніяк не використання на уроках сучасних інформаційно-комунікаційних технологій. Головним $є$ розвиток учнів - розумовий, загальнокультурний, духовний, фізичний (див. [16], [17]).

Як приклад невдалого подання змісту навчання розглянемо окремі публікації стосовно змісту навчання елементів теорії ймовірностей в навчальних закладах середньої освіти (див. [5], [7], [10]).

В статтях [5], [7] пропонується, даючи означення ймовірності (ймовірнісної міри), дотримуватися так званого класичного означення, де як простір $\Omega$ елементарних подій розглядається 
скінченна множина із $n$ рівноймовірних елементів, як простір $S$ подій - найширша сукупність підмножин множини $\Omega$ (див [10], [22]), а ймовірність події $A$, яка визначається через $m$ елементарних подій, покладається рівною $P(A)=\frac{m}{n}$. В таких публікаціях не звертається увага на протиріччя, що негайно виникають за такого підходу в разі нерівномірного розподілу ймовірностей на скінченній множині точок (наприклад $\Omega=\{1,2,3,4,5,6\}, \quad H_{1}=\{1,2,3,4\}, \quad H_{2}=\{5\}, \quad H_{3}=\{6\}$, $\left.S=\left\{A \mid A=\bigcup_{i \in I} H_{i}, I=\{1,2,3\}\right\}, \quad P\left(H_{1}\right)=0.10, \quad P\left(H_{2}\right)=0.30, \quad P\left(H_{3}\right)=0.60\right)$, або в разі дискретної зчисленної множини $\Omega=\{0,1,2, \ldots\}, S=S^{*}$ - найширша сукупність підмножини множини $\Omega$, $p_{m}=\frac{a^{m}}{m !} e^{-a}, m=0,1,2, \ldots$ (розподіл Пуассона), або в разі обмеженої неперервної множини $\Omega$ типу $\Omega=[a ; b],-\infty \leq a \leq b \leq \infty, S-$ сукупність всеможливих інтервалів із [a; $b]$ та їх об'єднань (див. [22]). Такі самі протиріччя виникають і в разі так званого «геометричного означення» ймовірностей $P([\alpha ; \beta])=\frac{(\beta-\alpha)}{b-a},[\alpha ; \beta] \subset[a ; b]$, оскільки окрім рівномірного розподілу ймовірностей на відрізку $[a ; b]$ існує безліч інших нерівномірних розподілів, зокрема найчастіше використовуваний на практиці, нормальний розподіл ймовірностей на множині $(-\infty ; \infty) 3$ щільністю $f(x)=\frac{1}{\sqrt{2 \pi \sigma}} e^{-\frac{(x-a)^{2}}{2 \sigma^{2}}}$, де $a, \sigma$-числові параметри розподілу ймовірностей, показниковий розподіл ймовірностей на множині $[0 ;+\infty)$ з щільністю $f(x)=\lambda e^{-\lambda x}, \lambda>0$-числовий параметр, що часто використовується в теорії масового обслуговування, і багато інших (див. [22]).

В зв'язку з наведеним доцільно зауважити, що єдиним несуперечливим означенням ймовірності $€$ так зване аксіоматичне означення ймовірності, запропоноване видатним російським математиком А.М. Колмогоровим в 30-х роках 20-го століття (див [22]). Як зазначає американський математик В. Феллер, тільки після того, як було запропоновано аксіоматичний підхід до побудови теорії ймовірностей, теорія ймовірностей стала розвиватися як справжня математична наука [18].

Зауважимо, що аксіоматичне означення ймовірності (ймовірнісної міри) майже дослівно (за винятком вимоги $P(\Omega)=1$, див [22]) співпадає з означенням площі плоскої фігури чи об'єму просторового тіла, що вивчаються в курсах геометрії в навчальних закладах середньої освіти за підручниками з геометрії О.В. Погорєлова [19], [20], що дає можливість використовувати відповідні аналогії в процесі навчання курсу теорії ймовірностей.

Разом 3 тим підхід до навчання основ теорії ймовірностей, що пропонується в цитованих публікаціях [5], [7], не тільки не розвиває в учнів наукове світобачення, а, навпаки, спотворює його, оскільки грунтується на не обгрунтованих, науково і педагогічно не виважених, хибних відправних положеннях, що, поза сумнівами, наносить шкоди розумовому, загальнокультурному і духовному розвитку учнів, формуванню їхнього наукового світобачення, становленню обізнаного в різних галузях знань високоосвіченого і висококультурного члена сучасного суспільства.

Слід зауважити також, що пропонований в [5] варіант комп’ютерної підтримки навчання основ теорії ймовірностей в школі $з$ використанням програмного засобу EXCEL швидше за все не $\epsilon$ педагогічно виваженим i доцільним. Схоже, що використання програмного засобу Gran1 за правильного підходу до навчання елементів теорії ймовірностей в школі було б набагато ефективнішим, ніж використання з такою метою засобу EXCEL (див., наприклад [22], [23]).

Що стосується «управління якістю освіти», то якщо «якість освіти» - це характеристики результатів, здобутих після завершення певного проміжку часу функціонування навчального закладу i перебігу в ньому навчально-пізнавальних процесів, показники, яких необхідно було досягти за вказаний період часу, то за логікою речей і сутністю розглядуваних понять управління потрібно здійснювати не характеристиками вже отриманих результатів, а процесами, перебіг яких приводить до таких результатів, систематично відслідковуючи окремі фази перебігу процесів і оцінюючи отримані проміжні результати і за результатами так здійснюваного оберненого зв'язку в розглядуваній системі управління в разі необхідності здійснювати коригування перебігу розглядуваного процесу за рахунок відповідних управлінських впливів, внесення певних змін в параметри управління процесом в разі відхилення проміжних результатів від наперед передбачуваних і запланованих. За так здійснюваного управління перебігом процесу з врахуванням умов, в яких перебігає контрольований процес, можна досягти якомога меншого відхилення характеристик отриманих результатів від 
наперед запланованих, які передбачалося і потрібно було досягти після завершення перебігу контрольованого процесу.

Наведене стосується також і «якості знань», отримуваних в процесі відповідної навчальнопізнавальної діяльності (див. [11]).

\section{Список використаних джерел:}

1. Моисеев Н.Н. Алгоритмы розвития. Москва, 1987. 304 с.

2. Суханов А.П. Информация и прогресс. Новосибирск, 1988. 192 с.

3. Шакотько В.В. Методична система формування інформологічних компетентностей майбутніх учителів інформатики: дис. ... канд. пед. наук.: 13.00.02 / Нац. б-ка України ім. В.I. Вернадського. Київ, 2018.

4. 4-та сторінка обкладинки журналу Комп 'ютер у школі та сім'ї. 2018. №1(145).

5. Івлієва О.M. Можливості застосування MS EXEL у процесі вивчення математичних дисциплін студентами-інформатиками. Комп ’ютер у школі та сім ’ï. 2018. №3(147). с. 3-9.

6. Сокол I.M., Нагорна Т.Ю. Використання Google Classroom на уроках математики. Комп 'ютер у школі та сім'ї. 2018. №2(146). с. 30-36

7. Навчальна програма 3 математики для учнів 10-11 класів загальноосвітніх навчальних закладів ( для класів з поглибленим вивченням математики ). Математика в рідній школі. 2016. №11. c. $2-17$

8. Тарасенкова Н. Комплексний підхід у навчанні математики: теоретичний аспект. Математика в рідній школі. 2016. №11. с.2-17.

9. Концедайло В.В. Застосування ігрових симуляторів у формуванні професійних компетентностей майбутніх інженерів-програмістів: автореф. дис. ... канд. пед. наук. Київ, 2018. 21 с.

10. Жалдак М.І. Вступ до теорії ймовірності і математичної статистики в шкільному курсі математики. Математика в рідній школі. 2017. №5 (187). с. 16-21.

11. Гончаренко С.У. Український педагогічний словник. Київ, 1997. 376 с.

12. Бусел В.Т. Великий тлумачний словник сучасної української мови. Київ, 2007. 1736 с.

13. Дистервег А. Избранные педагогические сочинения. Москва, 1956. 378 с.

14. Жалдак М.І., Морзе Н.В. Інформатика - 7. Київ, 2001. 208 с.

15. Англо-русский словарь. Москва, 1948. 800 с.

16. Жук Ю.О. Теоретико-методичні засади організації навчальної діяльності старшокласників в умовах комп’ютерно-орієнтованого середовища навчання: дис. ... д-ра пед. наук: 13.00.09 / Нац. б-ка України ім. В.I. Вернадського. Київ, 2017. 468 с.

17. Підгорна Т.В. Теоретико-методичні засади підготовки майбутніх учителів природничоматематичних дисциплін до професійної діяльності в умовах інформатизованого навчального процесу: дис. ... д-ра пед. наук: 13.00.02 / Нац. б-ка України ім. В.І. Вернадського. Київ, 2018. 503 с.

18. Феллер В. Введение в теорию вероятностей и её приложения. В 2 т. - Москва, 1964. 499 с.; T. 2. $1967.752 \mathrm{c}$.

19. Погорєлов О.В. Геометрія, Планіметрія. Підручник для 7-9 класів загальноосвітніх навчальних закладів. 7-ме видання. Київ, 2004. 240 с.

20. Погорєлов О.В. Геометрія. Стереометрія. Підручник для 10-11 класів середньої школи. 6-те видання. Київ, 2001. 128 с.

21. Колмогоров А.Н. Основные понятия теории вероятностей. Москва, 1974. 120 с.

22. Жалдак M.І., Кузьміна Н.М., Михалін Г.О. Теорія ймовірностей і математична статистика. Збірник вправ і задач. Навчальний посібник для студентів фізико-математичних та інформатичних спеціальностей педагогічних університетів. Видання друге. Перероблене і доповнене. Київ, 2019. 800 с. (Розміщено на сайті www.ktoi.npu.edu.ua. Поширюється безкоштовно).

23. Жалдак М.І., Горошко Ю.В., Вінниченко Є.Ф. Математика 3 комп’ютером. Посібник для вчителів. Київ, 2017. 252 с. (Розміщено на сайті www.ktoi.npu.edu.ua. Поширюється безкоштовно).

\section{References:}

1. Moyseev N.N. Alhorytmy rozvytyya. Moskva, 1987. 304 s.

2. Sukhanov A.P. Ynformatsyya y prohress. Novosybyrsk, 1988. $192 \mathrm{~s}$.

3. Shakot'ko V.V. Metodychna systema formuvannya informolohichnykh kompetentnostey maybutnikh uchyteliv informatyky: dys. ... kand. ped. nauk.: 13.00.02 / Nats. b-ka Ukrayiny im. V.I. Vernads'koho. Kyyiv, 2018.

4. 4-ta storinka obkladynky zhurnalu Komp"yuter u shkoli ta sim"yi. 2018. №1(145).

5. Ivliyeva O.M. Mozhlyvosti zastosuvannya MS EXEL u protsesi vyvchennya matematychnykh dystsyplin studentamy-informatykamy. Komp"yuter u shkoli ta sim"yi. 2018. №3(147). s. 3-9. 
6. Sokol I.M., Nahorna T.YU. Vykorystannya Google Classroom na urokakh matematyky. Komp"yuter u shkoli ta sim"yi. 2018. №2(146). s. 30-36

7. Navchal'na prohrama $\mathrm{z}$ matematyky dlya uchniv 10-11 klasiv zahal'noosvitnikh navchal'nykh zakladiv (dlya klasiv z pohlyblenym vyvchennyam matematyky). Matematyka v ridniy shkoli. 2016. №11. s. $2-17$

8. Tarasenkova N. Kompleksnyy pidkhid u navchanni matematyky: teoretychnyy aspekt. Matematyka v ridniy shkoli. 2016. №11. s. 2-17.

9. Kontsedaylo V.V. Zastosuvannya ihrovykh symulyatoriv u formuvanni profesiynykh kompetentnostey maybutnikh inzheneriv-prohramistiv: avtoref. dys. ... kand. ped. nauk. Kyyiv, 2018. $21 \mathrm{~s}$.

10. Zhaldak M.I. Vstup do teoriyi ymovirnosti i matematychnoyi statystyky v shkil'nomu kursi matematyky. Matematyka v ridniy shkoli. 2017. №5 (187). s. 16-21.

11. Honcharenko S.U. Ukrayins'kyy pedahohichnyy slovnyk. Kyyiv, 1997. 376 s.

12. Busel V.T. Velykyy tlumachnyy slovnyk suchasnoyi ukrayins'koyi movy. Kyyiv, 2007. 1736 s.

13. Dysterveh A. Yzbrannye pedahohycheskye sochynenyya. Moskva, 1956. 378 s.

14. Zhaldak M.I., Morze N.V. Informatyka - 7. Kyyiv, 2001. 208 s.

15. Anhlo-russkyy slovar'. Moskva, 1948. $800 \mathrm{~s}$.

16. Zhuk YU.O. Teoretyko-metodychni zasady orhanizatsiyi navchal'noyi diyal'nosti starshoklasnykiv v umovakh komp"yuterno-oriyentovanoho seredovyshcha navchannya: dys. ... d-ra ped. nauk: 13.00.09 / Nats. b-ka Ukrayiny im. V.I. Vernads'koho. Kyyiv, 2017. 468 s.

17. Pidhorna T.V. Teoretyko-metodychni zasady pidhotovky maybutnikh uchyteliv pryrodnychomatematychnykh dystsyplin do profesiynoyi diyal'nosti $\mathrm{v}$ umovakh informatyzovanoho navchal'noho protsesu: dys. ... d-ra ped. nauk: 13.00.02 / Nats. b-ka Ukrayiny im. V.I. Vernads'koho. Kyyiv, 2018. 503s.

18. Feller V. Vvedenye v teoryyu veroyatnostey y eë prylozhenyya. V 2 t. - Moskva, 1964. 499 s.; T. 2. 1967. $752 \mathrm{~s}$.

19. Pohoryelov O.V. Heometriya, Planimetriya. Pidruchnyk dlya 7-9 klasiv zahal'noosvitnikh navchal'nykh zakladiv. 7-me vydannya. Kyyiv, 2004. $240 \mathrm{~s}$.

20. Pohoryelov O.V. Heometriya. Stereometriya. Pidruchnyk dlya 10-11 klasiv seredn'oyi shkoly. 6-te vydannya. Kyyiv, 2001. $128 \mathrm{~s}$.

21. Kolmohorov A.N. Osnovnye ponyatyya teoryy veroyatnostey. Moskva, 1974. 120 s.

22. Zhaldak M.I., Kuz'mina N.M., Mykhalin H.O. Teoriya ymovirnostey i matematychna statystyka. Zbirnyk vprav i zadach. Navchal'nyy posibnyk dlya studentiv fizyko-matematychnykh ta informatychnykh spetsial'nostey pedahohichnykh universytetiv. Vydannya druhe. Pereroblene i dopovnene. Kyyiv, 2019. 800 s. (Rozmishcheno na sayti www.ktoi.npu.edu.ua. Poshyryuyet'sya bezkoshtovno).

23. Zhaldak M.I., Horoshko YU.V., Vinnychenko YE.F. Matematyka z komp"yuterom. Posibnyk dlya vchyteliv. Kyyiv, 2017. 252 s. (Rozmishcheno na sayti www.ktoi.npu.edu.ua. Poshyryuyet'sya bezkoshtovno).

\section{Zhaldak M.I.}

\section{Some features of ukrainian informatic terminology}

Abstract. The article is devoted to the analysis of some problems of the presentation of the content of Ukrainian-language scientific and pedagogical publications concerning the introduction of modern information and communication technologies in the educational process in institutions of secondary and higher education, their scientific and pedagogical accuracy and validity. In particular, the correctness of the terms "e-learning", "e-pedagogy", "interactive teaching aids", "interactive information systems", "cloud technology capabilities", "digital society", etc., approved of the type "competence is (being able to) perform certain actions, the relationship of the concepts of "competence" and "competencies".

Attention is drawn to the need to present the content of scientific and pedagogical publications at the highest possible literary and general cultural level in order to ensure their positive influence on the education and upbringing of students, the formation of their subject professional and general culture.

Keywords: ukrainian-language computer terminology, scientifically and pedagogically derived system of training and education, culture of scientific and pedagogical publications, activity and its structure, scientific approach to the interpretation of the terms used. 